\title{
Studi Efektivitas Pembelajaran Terpadu IImu Pengetahuan Sosial di Sekolah Menengah Pertama
}

\author{
Heni Waluyo Siswanto \\ Pusat Kurikulum dan Perbukuan, Balitbang Kemdiknas
}

\begin{abstract}
Abstrak: Studi ini bertujuan untuk menggali informasi mengenai: 1) kemampuan guru menjabarkan kompetensi IPS untuk melaksanakan pembelajaran terpadu; 2) pandangan guru yang masing-masing memiliki perbedaan latar belakang cabang keilmuan mengenai pembelajaran terpadu; dan 3) kemampuan guru melaksanakan pembelajaran terpadu yang efektif berbasis pada "team teaching". Penelitian diselenggarakan di 3 provinsi yang ditetapkan secara random purposif, yaitu: Semarang, Medan, dan Makassar. Hasil penelitian menunjukkan bahwa pembelajaran terpadu IPS di SMP, baik kategori baik maupun kategori sedang, tidak berlangsung secara efektif. Beberapa kendala yang menyebabkan ketidakefektifan yaitu: 1) kompetensi mata pelajaran IPS yang disebabkan oleh latar belakang pendidikan mereka yang berbasis cabang keilmuan; 2) pemaknaan yang tidak jelas terhadap misi pembelajaran terpadu IPS tampak dari pandangan guru IPS di SMP yang masing-masing memiliki perbedaan latar belakang cabang keilmuan, sehingga pembelajaran terpadu dilaksanakan hanya berdasarkan pada perspektif dan kemampuan individual masing-masing; dan 3) pelaksanaan pembelajaran terpadu IPS di SMP tidak bisa dilakukan secara optimal, karena terkendala keterbatasan alokasi waktu dan jadwal pelajaran yang tidak dirancang dan/atau disusun untuk kepentingan pembelajaran terpadu yang berbasis pada pendekatan "team teaching".
\end{abstract}

Kata kunci: efektifitas, pembelajaran terpadu, dan IPS.

\begin{abstract}
The aim of this study is to collect information regarding to: 1) the description of teachers ability to implement the competency of Integrated Learning of Social Sciences (IPS); 2) the view that each teacher has a different background of science discipline of integrated learning; and 3) the ability of teachers in implementing effective integrated learning based on "team teaching". Research conducted in 3 provinces assigned by purposively random, namely: Semarang, Medan, and Makassar. The result of the study shows a clear and significant result, that is the integrated learning social science in junior high school, both good category or medium category does not take place effectively. Some of the obstacles that led to the ineffectiveness of these are as follows: 1) the discrepancy ability of social studies teacher in junior high school is high enough to describe the competence of social science subjects due to their educational background of science discipline; 2 ) there is no clear meaning of mission from point of view of social science integrated learning teachers of junior high school who have different disciplines of science background, so that the integrated learning carried out only based on each individual perspectives and capabilities; 3 ) the implementation of social science integrated learning in junior high school can not be done optimally, because the allocation is constrained by the limitations of time and lessons schedule that are not designed and/or arranged for the benefit of an integrated learning approach based on "team teaching".
\end{abstract}

Key words: effectiveness; integrated learning; social studies

\section{Pendahuluan}

Secara historis, mata pelajaran Ilmu Pengetahuan Sosial (IPS) sudah dikenal dan diterapkan dalam Kurikulum SMP 1975, Kurikulum SMP 1984, Kurikulum SMP 1994, Kurikulum Berbasis Kompetensi atau Kurikulum SMP 2004, dan Kurikulum SMP 2006. Selanjutnya, nama IPS dikukuhkan dalam undang- undang, yakni Undang-Undang Nomor 20 Tahun 2003 tentang Sistem Pendidikan Nasional.

Selengkapnya, di dalam kedua undangundang tersebut dinyatakan bahwa kurikulum pendidikan dasar dan menengah wajib memuat: 1) pendidikan agama, 2) pendidikan kewarganegaraan, 3) bahasa, 4) matematika, 5) ilmu 
pengetahuan alam, 6) ilmu pengetahuan sosial, 7) seni dan budaya, 8) pendidikan jasmani dan olah raga, 9) keterampilan/kejuruan, dan 10) muatan lokal. Berdasarkan pada ketentuan itulah, IPS menjadi mata pelajaran yang wajib dimuat dalam kurikulum dan dibelajarkan kepada seluruh peserta didik pada jenjang pendidikan dasar dan jenjang pendidikan menengah.

Hakikat dari IPS SMP masing-masing merupakan mata pelajaran yang terpadu, sehingga kompetensi yang dituangkan dalam kurikulum dan pembelajaran kedua mata pelajaran tersebut mestinya disusun dengan pendekatan terpadu (integrated approach), dalam arti bahwa: 1) kurikulum IPS tidak lagi menunjukkan wajah masingmasing disiplin keilmuan; dan 2) pembelajarannya dilaksanakan oleh guru yang memiliki kemampuan konseptual IPS.

Secara konseptual, substansi IPS berasal dari konsep-konsep sejarah, geografi, ekonomi, sosiologi, dan antropologi. Implikasinya yaitu bahwa kedua mata pelajaran tersebut seharusnya telah dirancang sejak awal untuk memuat konsepkonsep yang terpadu atau terintegrasi antara satu dengan yang lainnya, sehingga dalam pembelajarannya pun sudah semestinya juga dilaksanakan secara terpadu.

Keterpaduan yang dimaksudkan akan membawa implikasi bahwa proses dan hasil pembelajaran IPS tidak lagi dalam bentuk terpisah-pisah sesuai dengan masing-masing karakteristik konsep setiap disiplin keilmuan. Oleh sebab itu, kompetensi IPS perlu dirumuskan secara inter-disipliner dan proses pembelajarannya pun perlu dilaksanakan secara terpadu, sehingga merupakan kesatuan utuh yang mencerminkan hakikat IPS. Namun demikian, muncul sejumlah pertanyaan yang perlu dijawab melalui penelitian, yaitu: 1) sejauhmana kompetensi IPS dipandang telah terpadu? 2) sejauhmana guru dapat menjabarkan kompetensi IPS ke dalam indikator materi pelajaran? dan 3) sejauhmana pembelajaran terpadu IPS dipandang telah efektif?

Sejauh ini, penelitian terhadap hal tersebut belum pernah dilakukan oleh para peneliti dalam bidang pendidikan di Indonesia, sehingga tidak ada referensi sebagai empirik awal yang dapat digunakan sebagai acuan untuk melakukan penelitian sejenis. Oleh karena itu, Peneliti sangat memandang perlu untuk menyelenggarakan penelitian terhadap efektivitas dari pembelajaran terpadu IPS di SMP.

Masalah utama yang memunculkan perlunya pembelajaran terpadu IPS yaitu antara lain: 1) rumusan kompetensi mata pelajaran IPS masih menggunakan pendekatan terpisah (separated approach) sesuai dengan karakteristik masingmasing konsep dasar dari cabang keilmuannya; dan 2) guru yang mengajar IPS mempunyai latar belakang pendidikan salah satu cabang keilmuan yang menjadi cakupan konseptual kedua mata pelajaran tersebut.

Kondisi semacam itu telah memunculkan permasalahan dalam pelaksanaan pembelajaran IPS yang antara lain sebagai berikut: 1) Guru menghadapi kesulitan untuk menjabarkan kompetensi mata pelajaran IPS yang berbasis cabang keilmuan untuk kepentingan pembelajaran terpadu; 2) Guru yang berlatar belakang cabang keilmuan tertentu menghadapi kesulitan untuk melaksanakan pembelajaran terpadu dengan guru lainnya yang berbeda latar belakang cabang keilmuan; dan 3) Guru menghadapi kesulitan untuk melaksanakan pembelajaran terpadu yang efektif karena dengan keterbatasan alokasi waktu dan jadwal pelajaran yang tidak dirancang dan tidak disusun untuk kepentingan pembelajaran terpadu berbasis pada "team teaching".

Tujuan penelitian ini adalah untuk menggali informasi tentang: 1) Kemampuan guru menjabarkan kompetensi IPS untuk melaksanakan pembelajaran terpadu, 2) Pandangan guru yang masing-masing memiliki perbedaan latar belakang cabang keilmuan mengenai pembelajaran terpadu; dan 3) kemampuan guru melaksanakan pembelajaran terpadu yang efektif berbasis pada "team teaching".

\section{Kajian Literatur Hakikat IPS}

Istilah IPS dalam kepustakaan asing dikenal dengan "Social Studies" atau "Social Science Education". IPS merupakan mata pelajaran yang mengintegrasikan konsep-konsep dari berbagai cabang ilmu-ilmu sosial, yaitu: ekonomi, geografi, sejarah, hukum, politik, sosiologi, antropologi, filosofi, dan psikologi. Hal ini sejalan dengan 
pengertian Social Studies yang dirumuskan oleh National Council for the Social Studies atau NCSS (1994) bahwa: Social Studies is the integrated study of the social science and humanities to promote civic competence. Within the school program, social studies provides coordinated, systematic study drawing upon such disciplines as anthropology, economics, geography, history, law, philosophy, political science, psychology, religion, and sociology, as well as appropriate content from the humanities, mathematics, and natural sciences. The primary purpose of social studies is to help young people develop the ability to make informed and reasoned decisions for the public good as citizens of culturally diverse, democratic society in an interdependent world.

Tujuan IPS yaitu untuk membantu peserta didik dalam menguasai, memahami, dan mengembangkan kemampuan yang berkaitan permasalahan sosial. Melalui IPS tersebut diharapkan peserta didik dapat berpikir secara rasional dan kritis dalam menanggapi isu-isu sosial dan membuat keputusan berdasarkan pada pengolahan informasi. Dengan demikian, peserta didik dapat berpartisipasi sebagai warga negara sesuai kemampuan yang dimilikinya. Oleh karena itu, untuk membelajarkan materi ilmu pengetahuan sosial yang dapat membantu peserta didik mengembangkan kemampuan membuat keputusan publik yang baik, diperlukan tenaga pendidik (guru atau dosen) yang memiliki kemampuan dan penguasaan dalam mengorganisasikan materimateri tersebut. Secara lengkap NCSS (Volume 1, 2000: 79) merumuskan sepuluh standar tematik untuk guru IPS, yaitu: Social studies teachers should possess the knowledge, capabilities, and dispositions to organize and provide instruction at the appropriate school level for the study of (I) Culture and cultural diversity (II) Time, continuity, and change; (III) People, places, and environment; (IV) Individual development and identity; (V) Individuals, groups, and institutions; (VI) Power, authority, and governance; (VII) Production, distribution, and consumption; (VIII) Science, technology, and society; (IX) Global connections; $(X)$ Civic ideals and practices.

Dengan demikian, dapat dipahami bahwa guru IPS harus memiliki kemampuan untuk mengorganisir materi yang telah disebutkan di atas sebagai isi/konten dari ilmu-ilmu sosial. Rumusan IPS dan standar guru IPS yang dikemukakan oleh NCSS saling mendukung, artinya bahwa untuk membelajarkan materi yang terdapat dalam IPS dibutuhkan guru yang memiliki pengetahuan, kemampuan, dan sikap yang diharapkan dalam isi/konten IPS.

Sebenarnya konsep tentang pendidikan ilmu sosial sudah sejak lama dikemukakan oleh Dewey (1934), yaitu: Advanced social education for its potential to develop critical democratic citizens and cultural diversity, conservatives, reflecting the interests of capitalists and cultural conservatives, have promoted social education as a means of supporting economic productivity, nationalism, and conservative morality. Dewey memandang pendidikan ilmu sosial jauh ke depan, bukan hanya mempelajari tentang disiplin ilmu-ilmu sosial, namun lebih jauh menekankan pada "outcome" dari mempelajari ilmu sosial. Artinya bahwa dengan mempelajari ilmu-ilmu sosial peserta didik diharapkan memiliki sikap kritis, menyadari adanya keberagaman seperti adanya penganut kapitalis dan konservatif. Selanjutnya berdasarkan pada sikap dan kesadaran tersebut peserta didik dapat mendorong meningkatnya produktifitas ekonomi, meningkatkan nasionalisme, dan moral konservatif.

Shaver dan Berlak (1968) merinci beberapa makna IPS bahwa: Social studies as most frequently used in the educational literature, refers to the disciplines of the social sciences taken singly or collectively and simplified for pedagogical purposes. A second meaning given to the term is as a general label for all the disciplines concerned with the study of man and society. Third, the social studies has been viewed as an educational program composed. Fourth, the term social studies has been used somewhat amorphously to refer to all (curricular and non-curricular) activities of the school that are related to the socialization of youngsters in the society. This last meaning, which is more prevalent at the elementary school level, frequently muddles or ignores distinctions between systemic inquiry in any of the social sciences or the humanities.

Shaver dan Berlak lebih menekankan pada pengorganisasian disiplin ilmu-ilmu sosial, seperti bagaimana ilmu-ilmu sosial disederhanakan untuk tujuan pendidikan, bahwa ilmu sosial merupakan 
program pendidikan yang baik bagi masyarakat, dan ilmu sosial bersifat dinamis dalam program sekolah. Jadi pandangan Shaver dan Berlak lebih bersifat perencanaan secara konseptual, belum mengarah kepada hasil dari pembelajaran IPS seperti yang dikemukakan oleh Dewey.

Hursh dan Ross (2000: 10) mengemukakan bahwa: Social studies to a supporting role in schools (or, worse, using social studies to produce docile citizens), we can broaden social studies to include multicultural, media, artistic, and literacy studies in order to analyze and transform the economic, political, and cultural forces in our society, indeed, in the chapters that follow, the authors suggest that when schools become places where student and teachers together raise question about issues important to their lives - such as questions about students' racial, gender, and class identities, or about local community issues - the larger historical and political questions gain significance.

Pandangan Hursh dan Ross lebih komprehensif, karena pembelajaran IPS sudah diarahkan pada pembelajaran yang berisi berbagai disiplin ilmu sosial termasuk media dan seni. Mereka juga mengemukakan tentang proses pembelajarannya yakni dengan menjadikan sekolah sebagai tempat dimana peserta didik dan pengajar secara bersama-sama dapat membahas isu-isu penting yang muncul dalam kehidupan masyarakat. Selanjutnya melakukan analisis terhadap isu tersebut, seperti masalah suku, jender, dan masalah aktual lainnya untuk mengubah kondisi masyarakat, baik dari segi ekonomi, politik, maupun budaya.

Berdasarkan paparan tentang IPS diatas, dapat disimpulkan bahwa pada prinsipnya IPS mempelajari tentang ilmu-ilmu sosial seperti ekonomi, geografi, sejarah, sosiologi, hukum, ilmu politik, antropologi, psikologi, dan filosofi. Materi tersebut dipelajari sebagai upaya mengembangkan kemampuan dan ketrampilan warga negara dalam mengembangkan sikap kritis, membuat keputusan publik yang baik, mengembangkan sikap demokratis, sehingga menghasilkan warga negara yang baik. Dengan kemampuan dan keterampilan demikian diharapkan warga negara dapat berpartisipasi dalam kehidupan masyarakat, bangsa, dan negaranya.

\section{Mata Pelajaran IPS SMP}

Ilmu Pengetahuan Sosial (IPS) merupakan salah satu mata pelajaran yang diberikan mulai dari SD/ MI/SDLB sampai SMP/MTs/SMPLB. IPS mengkaji seperangkat peristiwa, fakta, konsep, dan generalisasi yang berkaitan dengan isu sosial. Pada jenjang SMP/MTs mata pelajaran IPS memuat materi Geografi, Sejarah, Sosiologi, dan Ekonomi. Melalui mata pelajaran IPS, peserta didik diarahkan untuk dapat menjadi warga negara Indonesia yang demokratis, dan bertanggung jawab, serta warga dunia yang cinta damai.

Di masa yang akan datang peserta didik akan menghadapi tantangan berat karena kehidupan masyarakat global selalu mengalami perubahan setiap saat. Oleh karena itu mata pelajaran IPS dirancang untuk mengembangkan pengetahuan, pemahaman, dan kemampuan analisis terhadap kondisi sosial masyarakat dalam memasuki kehidupan bermasyarakat yang dinamis.

Mata pelajaran IPS disusun secara sistematis, komprehensif, dan terpadu dalam proses pembelajaran menuju kedewasaan dan keberhasilan dalam kehidupan di masyarakat. Dengan pendekatan tersebut diharapkan peserta didik akan memperoleh pemahaman yang lebih luas dan mendalam pada bidang ilmu yang berkaitan.

Mata pelajaran IPS bertujuan agar peserta didik memiliki kemampuan: 1) Mengenal konsepkonsep yang berkaitan dengan kehidupan masyarakat dan lingkungannya, 2) Memiliki kemampuan dasar untuk berpikir logis dan kritis, rasa ingin tahu, inkuiri, memecahkan masalah, dan keterampilan dalam kehidupan sosial, 3) Memiliki komitmen dan kesadaran terhadap nilai-nilai sosial dan kemanusiaan, 4) Memiliki kemampuan berkomunikasi, bekerjasama dan berkompetisi dalam masyarakat yang majemuk, di tingkat lokal, nasional, dan global.

\section{Kompetensi IPS SMP}

Kompetensi yang dijadikan acuan bagi penyusunan silabus, rencana pelaksanaan pembelajaran, dan proses pembelajaran IPS adalah sebagaimana yang dimuat dalam Permendiknas No. 22 tahun 2006 tentang Standar Isi, seperti yang termuat dalam tabel-tabel berikut ini. 
Tabel 1. Kompetensi IPS Kelas VII Semester 1

\begin{tabular}{|c|c|}
\hline Standar Kompetensi & Kompetensi Dasar \\
\hline $\begin{array}{l}\text { 1. Memahami lingkungan } \\
\text { kehidupan manusia }\end{array}$ & $\begin{array}{l}\text { 1.1 Mendeskripsikan keragaman bentuk muka bumi, proses } \\
\text { pembentukan, dan dampaknya terhadap kehidupan } \\
\text { 1.2 Mendeskripsikan kehidupan pada masa pra-aksara di } \\
\text { Indonesia }\end{array}$ \\
\hline $\begin{array}{l}\text { 2. Memahami kehidupan } \\
\text { sosial manusia }\end{array}$ & $\begin{array}{l}\text { 2.1 Mendeskripsikan interaksi sebagai proses sosial } \\
\text { 2.2 Mendeskripsikan sosialisasi sebagai proses pembentukan } \\
\text { kepribadian } \\
\text { 2.3 Mengidentifikasi bentuk-bentuk interaksi sosial } \\
\text { 2.4 Menguraikan proses interaksi sosial }\end{array}$ \\
\hline $\begin{array}{l}\text { 3. Memahami usaha } \\
\text { manusia memenuhi } \\
\text { kebutuhan }\end{array}$ & $\begin{array}{l}\text { 3.1 Mendeskripsikan manusia sebagai makhluk sosial dan } \\
\text { ekonomi yang bermoral dalam memenuhi kebutuhan } \\
\text { 3.2 Mengidentifikasi tindakan ekonomi berdasarkan motif } \\
\text { dan prinsip ekonomi dalam berbagai kegiatan sehari-hari }\end{array}$ \\
\hline
\end{tabular}

Tabel 2. Kompetensi IPS Kelas VII Semester 2

\begin{tabular}{|c|c|}
\hline Standar Kompetensi & Kompetensi Dasar \\
\hline $\begin{array}{l}\text { 4. Memahami usaha } \\
\text { manusia untuk } \\
\text { mengenali } \\
\text { perkembangan } \\
\text { lingkungannya }\end{array}$ & $\begin{array}{l}\text { 4.1 Menggunakan peta, atlas, dan globe untuk mendapatkan } \\
\text { informasi keruangan } \\
\text { 4.2 Membuat sketsa dan peta wilayah yang menggambarkan } \\
\text { objek geografi } \\
\text { 4.3 Mendeskripsikan kondisi geografis dan penduduk } \\
\text { 4.4 Mendeskripsikan gejala-gejala yang terjadi di atmosfer } \\
\text { dan hidrosfer, serta dampaknya terhadap kehidupan }\end{array}$ \\
\hline $\begin{array}{l}\text { 5. Memahami } \\
\text { perkembangan } \\
\text { masyarakat sejak masa } \\
\text { Hindu-Budha sampai } \\
\text { masa Kolonial Eropa }\end{array}$ & $\begin{array}{l}\text { 5.1 Mendeskripsikan perkembangan masyarakat, } \\
\text { kebudayaan dan pemerintahan pada masa Hindu-Budha, } \\
\text { serta peninggalan-peninggalannya } \\
\text { 5.2 Mendeskripsikan perkembangan masyarakat, } \\
\text { kebudayaan, dan pemerintahan pada masa Islam di } \\
\text { Indonesia, serta peninggalan-peninggalannya } \\
\text { 5.3 Mendeskripsikan perkembangan masyarakat, } \\
\text { kebudayaan dan pemerintahan pada masa Kolonial Eropa }\end{array}$ \\
\hline $\begin{array}{l}\text { 6. Memahami kegiatan } \\
\text { ekonomi masyarakat }\end{array}$ & $\begin{array}{l}\text { 6.1 Mendeskripsikan pola kegiatan ekonomi penduduk, } \\
\text { penggunaan lahan dan pola permukiman berdasarkan } \\
\text { kondisi fisik permukaan bumi } \\
\text { 6.2 Mendeskripsikan kegiatan pokok ekonomi yang meliputi } \\
\text { kegiatan konsumsi, produksi, dan distribusi barang/jasa } \\
\text { 6.3 Mendeskripsikan peran badan usaha, termasuk koperasi, } \\
\text { sebagai tempat berlangsungnya proses produksi dalam } \\
\text { kaitannya dengan pelaku ekonomi } \\
\text { 6.4 Mengungkapkan gagasan kreatif dalam tindakan ekonomi } \\
\text { untuk mencapai kemandirian dan kesejahteraan }\end{array}$ \\
\hline
\end{tabular}

Tabel 3. Kompetensi IPS Kelas VIII Semester 1

\begin{tabular}{|c|c|}
\hline Standar Kompetensi & Kompetensi Dasar \\
\hline $\begin{array}{l}\text { 1. Memahami } \\
\text { permasalahan sosial } \\
\text { berkaitan dengan } \\
\text { pertumbuhan jumlah } \\
\text { penduduk }\end{array}$ & $\begin{array}{l}\text { 1.1 Mendeskripsikan kondisi fisik wilayah dan penduduk } \\
\text { 1.2 Mengidentifikasi permasalahan kependudukan dan upaya } \\
\text { penanggulangannya } \\
\text { 1.3 Mendeskripsikan permasalahan lingkungan hidup dan } \\
\text { upaya penanggulangannya dalam pembangunan } \\
\text { berkelanjutan } \\
\text { 1.4 Mendeskripsikan permasalahan kependudukan dan } \\
\text { dampaknya terhadap pembangunan }\end{array}$ \\
\hline
\end{tabular}




\begin{tabular}{|c|c|}
\hline $\begin{array}{l}\text { 2. Memahami proses } \\
\text { kebangkitan nasional }\end{array}$ & $\begin{array}{l}2.1 \text { Menjelaskan proses perkembangan kolonialisme dan } \\
\text { imperialisme Barat, serta pengaruh yang ditimbulkannya di } \\
\text { berbagai daerah } \\
\text { 2.2 Menguraikan proses terbentuknya kesadaran nasional, } \\
\text { identitas Indonesia, dan perkembangan pergerakan } \\
\text { kebangsaan Indonesia }\end{array}$ \\
\hline $\begin{array}{l}\text { 3. Memahami masalah } \\
\text { penyimpangan sosial }\end{array}$ & $\begin{array}{l}\text { 3.1 Mengidentifikasi berbagai penyakit sosial (miras, judi, } \\
\text { narkoba, HIV/Aids, PSK, dan sebagainya) sebagai akibat } \\
\text { penyimpangan sosial dalam keluarga dan masyarakat } \\
\text { 3.2 Mengidentifikasi berbagai upaya pencegahan } \\
\text { penyimpangan sosial dalam keluarga dan masyarakat }\end{array}$ \\
\hline $\begin{array}{l}\text { 4. Memahami kegiatan } \\
\text { pelaku ekonomi di } \\
\text { masyarakat }\end{array}$ & $\begin{array}{l}\text { 4.1 Mendeskripsikan hubungan antara kelangkaan sumber } \\
\text { daya dengan kebutuhan manusia yang tidak terbatas } \\
\text { 4.2 Mendeskripsikan pelaku ekonomi: rumah tangga, } \\
\text { masyarakat, perusahaan, koperasi, dan negara } \\
\text { 4.3 Mengidentifikasi bentuk pasar dalam kegiatan ekonomi } \\
\text { masyarakat }\end{array}$ \\
\hline
\end{tabular}

Tabel 4. Kompetensi IPS Kelas VIII Semester 2

\begin{tabular}{|c|c|}
\hline Standar Kompetensi & Kompetensi Dasar \\
\hline $\begin{array}{l}\text { 5. Memahami usaha } \\
\text { persiapan } \\
\text { kemerdekaan }\end{array}$ & $\begin{array}{l}\text { 5.1 Mendeskripsikan peristiwa-peristiwa sekitar proklamasi } \\
\text { dan proses terbentuknya negara kesatuan Republik } \\
\text { Indonesia } \\
\text { 5.2 Menjelaskan proses persiapan kemerdekaan Indonesia }\end{array}$ \\
\hline $\begin{array}{l}\text { 6. Memahami pranata } \\
\text { dan penyimpangan } \\
\text { sosial }\end{array}$ & $\begin{array}{l}\text { 6.1 Mendeskripsikan bentuk-bentuk hubungan sosial } \\
\text { 6.2 Mendeskripsikan pranata sosial dalam kehidupan } \\
\text { masyarakat } \\
\text { 6.3 Mendeskripsikan upaya pengendalian penyimpangan sosial }\end{array}$ \\
\hline $\begin{array}{l}\text { 7. Memahami kegiatan } \\
\text { perekonomian } \\
\text { Indonesia }\end{array}$ & $\begin{array}{l}\text { 7.1 Mendeskripsikan permasalahan angkatan kerja dan tenaga } \\
\text { kerja sebagai sumber daya dalam kegiatan ekonomi, serta } \\
\text { peranan pemerintah dalam upaya penanggulangannya } \\
\text { 7.2 Mendeskripsikan pelaku-pelaku ekonomi dalam sistem } \\
\text { perekonomian Indonesia } \\
\text { 7.3 Mendeskripsikan fungsi pajak dalam perekonomian } \\
\text { nasional } \\
\text { 7.4 Mendeskripsikan permintaan dan penawaran serta } \\
\text { terbentuknya harga pasar }\end{array}$ \\
\hline
\end{tabular}

Tabel 5. Kompetensi IPS Kelas IX Semester 1

\begin{tabular}{|c|c|}
\hline Standar Kompetensi & Kompetensi Dasar \\
\hline $\begin{array}{l}\text { 1. Memahami kondisi } \\
\text { perkembangan negara } \\
\text { di dunia }\end{array}$ & $\begin{array}{l}\text { 1.1 Mengidentifikasi ciri-ciri negara berkembang dan negara } \\
\text { maju } \\
\text { 1.2 Mendeskripsikan Perang Dunia II (termasuk pendudukan } \\
\text { Jepang) serta pengaruhnya terhadap keadaan sosial, } \\
\text { ekonomi, dan politik di Indonesia }\end{array}$ \\
\hline $\begin{array}{l}\text { 2. Memahami usaha } \\
\text { mempertahankan } \\
\text { kemerdekaan }\end{array}$ & $\begin{array}{l}\text { 2.1 Mengidentifikasi usaha perjuangan mempertahankan } \\
\text { kemerdekaan Indonesia } \\
\text { 2.2 Mendeskripsikan peristiwa-peristiwa politik dan ekonomi } \\
\text { Indonesia pasca pengakuan kedaulatan }\end{array}$ \\
\hline $\begin{array}{l}\text { 3. Memahami perubahan } \\
\text { sosial budaya }\end{array}$ & $\begin{array}{l}\text { 3.1 Mendeskripsikan perubahan sosial-budaya pada } \\
\text { masyarakat } \\
\text { 3.2 Menguraikan tipe-tipe perilaku masyarakat dalam } \\
\text { menyikapi perubahan }\end{array}$ \\
\hline $\begin{array}{l}\text { 4. Memahami lembaga } \\
\text { keuangan dan } \\
\text { perdagangan } \\
\text { internasional }\end{array}$ & $\begin{array}{l}\text { 4.1 Mendeskripsikan uang dan lembaga keuangan } \\
\text { 4.2 Mendeskripsikan perdagangan internasional dan } \\
\text { dampaknya terhadap perekonomian Indonesia }\end{array}$ \\
\hline
\end{tabular}


Tabel 6. Kompetensi IPS Kelas IX Semester 2

\begin{tabular}{|c|c|}
\hline Standar Kompetensi & Kompetensi Dasar \\
\hline $\begin{array}{l}\text { 5. Memahami hubungan } \\
\text { manusia dengan bumi }\end{array}$ & $\begin{array}{l}\text { 5.1 Menginterpretasi peta tentang bentuk dan pola muka bumi } \\
\text { 5.2 Mendeskripsikan keterkaitan unsur-unsur geografis dan } \\
\text { penduduk di kawasan Asia Tenggara } \\
\text { 5.3 Mendeskripsikan pembagian permukaan bumi atas benua } \\
\text { dan samudera }\end{array}$ \\
\hline $\begin{array}{l}\text { 6. Memahami usaha } \\
\text { mempertahankan } \\
\text { Republik Indonesia }\end{array}$ & $\begin{array}{l}\text { 6.1 Mendeskripsikan perjuangan bangsa Indonesia merebut } \\
\text { Irian Barat } \\
\text { 6.2 Mendeskripsikan peristiwa tragedi nasional Peristiwa } \\
\text { Madiun/PKI, DI/TII, G } 30 \text { S/PKI dan konflik-konflik internal } \\
\text { lainnya }\end{array}$ \\
\hline $\begin{array}{l}\text { 7. Memahami perubahan } \\
\text { pemerintahan dan } \\
\text { kerjasama } \\
\text { internasional }\end{array}$ & $\begin{array}{l}\text { 7.1 Menjelaskan berakhirnya masa Orde Baru dan lahirnya } \\
\text { Reformasi } \\
\text { 7.2 Menguraikan perkembangan lembaga-lembaga internasional } \\
\text { dan peran Indonesia dalam kerjasama internasional } \\
\text { 7.3 Menguraikan perilaku masyarakat dalam perubahan sosial- } \\
\text { budaya di era global } \\
\text { 7.4 Mendeskripsikan kerjasama antarnegara di bidang ekonomi } \\
\text { 7.5 Mengidentifikasi dampak kerjasama antarnegara terhadap } \\
\text { perekonomian Indonesia }\end{array}$ \\
\hline
\end{tabular}

\section{Pembelajaran Terpadu}

Model pembelajaran terpadu telah digunakan di Indonesia, karena merupakan salah satu model implementasi kurikulum yang dianjurkan untuk diaplikasikan pada semua jenjang pendidikan pada jenjang pendidikan dasar dan menengah. Tuntutan untuk melaksanakan pembelajaran terpadu sebenarnya sudah cukup lama. Hal itu tampak dari panduan yang pernah dikeluarkan oleh Departemen Pendidikan dan Kebudayaan tahun 1996 yang menjelaskan bahwa model pembelajaran terpadu pada hakikatnya merupakan suatu pendekatan pembelajaran yang memungkinkan peserta didik baik secara individual maupun kelompok aktif mencari, menggali, dan menemukan konsep serta prinsip secara holistik dan otentik.

Shoemaker (1989) mengartikan pembelajaran terpadu is organized in such a way that it cuts across subject-matter lines, bringing together various aspects of the curriculum into meaningful association to focus upon broad areas of study. It views learning and teaching in a holistic way and reflects the real world, which is interactive. Menurut Shoemaker selanjutnya bahwa using an integrated teaching to teach is a strategy based on the premise that learning is a series of connections. The integrated curriculum can be beneficial to teachers and students, using theme teaching, projects, and units to cover a variety of material and effectively teach many concepts and skills.
Melalui pembelajaran terpadu peserta didik dapat memperoleh pengalaman langsung, sehingga dapat menambah kekuatan untuk menerima, menyimpan, dan memproduksi kesankesan tentang hal-hal yang dipelajarinya. Dengan demikian, peserta didik terlatih untuk dapat menemukan sendiri berbagai konsep yang dipelajari secara holistik, bermakna, otentik, dan aktif.

Pembelajaran terpadu, menurut Klein (1996), bahwa "... comes in many varieties: connecting skills and knowledge from multiple sources and experiences; applying skills and practices in various settings; utilizing diverse and even contradictory points of view; and, understanding issues and positions contextually." Hal itu didukung oleh Huber \& Gale (2005) yang menyatakan bahwa pembelajaran terpadu adalah "... making connections within a major, between fields, between curriculum, co curriculum, or between academic knowledge and practice."

Pembelajaran terpadu terutama guru memungkinkan untuk mengambil manfaat dengan mambangun jaringan di antara guru itu sendiri. Kebermanfaatan tersebut, menurut Krogh (1990), bahwa teachers can create a good deal of their curriculum by building webs made up of themes of interest to the children, with benefits for all. These benefits include more adequate coverage of curriculum, use of natural learning, building on children's interests, teaching skills in meaningful 
contexts, more flexibility, and an organized planning device.

Pembelajaran terpadu harus bisa menjembatani tiga kepentingan, yaitu guru, peserta didik, dan konteks nyata (real life scenarios) sebagai sumber dukungan pembelajaran tersebut. Dengan demikian, peserta didik mempunyai kesempatan besar untuk memperoleh pengalaman belajar dengan informasi yang relevan dan menerapkannya sesuai fakta yang diperolehnya. Mereka dapat menggunakan lingkungan yang mendorong proses belajar dengan keterlibatan aktif yang dibangun oleh mereka sendiri.

Dalam kaitan itu, Fisher (1991) menyatakan bahwa they build on students' interests and prior knowledge by focusing on topics relevant to their lives. They help children relate to real-life experiences and build on what they know. Kostelnik, et all (2004) merumuskan keuntungan dari pembelajaran terpadu sebagai berikut: 1) Learning in-depth factual information, 2) Becoming physically involved with learning, 3) Learning process skills, 4) Learning "how to learn", 5) Integrating learning in a holistic way, 6) Promoting group cohesiveness, 7) Addressing individual needs, dan 8) Motivating children and teachers.

Selanjutnya, Kostelnik menyatakan bahwa the connections can be made among different subject areas, including math, science, social studies, and literacy as well as art, music, dramatic play, and physical activities. These connections help children in the way they learn best - through meaningful experiences. This also allows children to learn through their preferred learning modalities.

\section{Metodologi Penelitian}

Penelitian ini merupakan "descriptive research" yang bertujuan untuk menentukan tingkat hubungan antar aspek: 1) kemampuan guru menjabarkan kompetensi IPS untuk melaksanakan pembelajaran terpadu; 2) pandangan guru yang masing-masing memiliki perbedaan latar belakang cabang keilmuan untuk melaksanakan pembelajaran terpadu; dan 3) kemampuan guru untuk melaksanakan pembelajaran terpadu yang efektif dengan keterbatasan alokasi waktu dan jadwal pelajaran yang tidak dirancang dan disusun untuk kepentingan pembelajaran terpadu berbasis pada "team teaching".
Rancangan hubungan antar aspek tersebut dalam masing-masing mata pelajaran adalah sebagaimana yang divisualisasikan sebagai berikut ini.

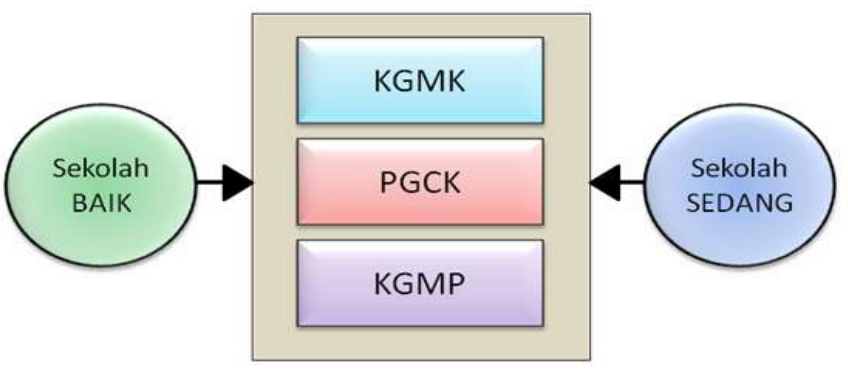

Gambar 1. Rancangan Penelitian

Mengacu pada gambar 1 dapat dijelaskan bahwa variabel penelitian dalam mata pelajaran IPS adalah: 1) Kemampuan Guru Menjabarkan Kompetensi (KGMK), 2) Pandangan Guru Cabang Keilmuan (PGCK), 3) Kemampuan Guru Melaksanakan Pembelajaran (KGMP).

\section{Waktu, Tempat, dan Sampel}

Penelitian ini dilakukan antara tanggal 15 s.d 19 November 2010. Tempat penelitian di 3 provinsi yang ditetapkan secara random purposif, yaitu: Jawa Tengah (Semarang), Sumatera Utara (Medan), dan Sulawesi Selatan (Makassar). Populasi penelitian adalah seluruh SMP yang berada di ketiga provinsi tersebut. Sampel sekolah dipilih secara random dengan mengacu pada kriteria baik dan sedang. Seluruh guru IPS pada SMP yang terpilih menjadi fokus penelitian dengan berdasarkan pada kriteria baik, sedang, dan kurang sekaligus menjadi unit analisis atau responden penelitian. Rincian mengenai hal tersebut sebagaimana tampak dalam ilustrasi berikut ini.

\section{Teknik Pengumpulan Data}

Penelitian ini menggunakan metode survei yang dilakukan secara langsung ke lokasi penelitian (directed survey) oleh para Peneliti. Penggunaan metode ini dimaksudkan untuk memperoleh sejumlah informasi mengenai efektivitas pembelajaran terpadu IPS dari para pendidik yang mengajar IPS secara langsung di lokasi penelitian.

Pengumpulan data dilakukan dengan cara pengisian kuesioner oleh seluruh responden dari 
Tabel 1. Penetapan Jumlah SMP Sampel, Kriteria, dan Responden

\begin{tabular}{|c|c|c|c|c|}
\hline NO. & PROVINSI & SMP TERPILIH & KRITERIA & $\begin{array}{c}\text { RESPONDEN } \\
\text { IPS }\end{array}$ \\
\hline 1. & Jawa Tengah & $\begin{array}{l}\text { SMP } 5 \text { Semarang } \\
\text { SMP } 6 \text { Semarang }\end{array}$ & $\begin{array}{c}\text { Baik } \\
\text { Sedang }\end{array}$ & $\begin{array}{l}3 \\
3\end{array}$ \\
\hline 2. & Sumatera Utara & $\begin{array}{l}\text { SMP } 14 \text { Medan } \\
\text { SMP } 18 \text { Medan }\end{array}$ & $\begin{array}{c}\text { Baik } \\
\text { Sedang }\end{array}$ & $\begin{array}{l}3 \\
3\end{array}$ \\
\hline 3. & $\begin{array}{l}\text { Sulawesi } \\
\text { Selatan }\end{array}$ & $\begin{array}{l}\text { SMP } 12 \text { Makasar } \\
\text { SMP } 24 \text { Makasar }\end{array}$ & $\begin{array}{c}\text { Baik } \\
\text { Sedang }\end{array}$ & $\begin{array}{l}3 \\
3 \\
\end{array}$ \\
\hline$\Sigma$ & 3 provinsi & 6 SMP & 3 Baik \& 3 Sedang & 18 \\
\hline
\end{tabular}

SMP yang telah ditetapkan sebagai lokus pengambilan data di 3 provinsi. Untuk menggali informasi lainnya, pengumpulan data dilengkapi dengan diskusi kelompok.

\section{Teknik Analisis Data}

Selanjutnya, data yang diperoleh dari responden diolah secara deskriptif sebagai bahan analisis

\section{Hasil Penelitian dan Pembahasan}

Data hasil penelitian yang diperoleh dari responden guru IPS dengan kategori Baik dan Sedang disajikan masing-masing di bawah ini.

Data skor pembelajaran terpadu IPS dari guru IPS pada SMP dengan kategori Baik dan Sedang secara statistik deskriptif diperoleh gambaran sebagai berikut:

Tabel 2. Statistik Deskriptif Data Skor IPS

Des criptive Statistics

\begin{tabular}{|l|r|r|r|r|r|}
\hline & $\mathrm{N}$ & Minimum & Maximum & Mean & Std. Deviation \\
\hline Baik & 18 & 2.00 & 9.00 & 6.7778 & 2.48657 \\
Sedang & 18 & 3.00 & 9.00 & 6.8889 & 2.32351 \\
Valid N (listwise) & 18 & & & & \\
\hline
\end{tabular}

dan pembahasan terhadap temuan penelitian dan sekaligus dalam rangka menjawab pertanyaan penelitian. Untak melengkapi data utama yang diperoleh melalui kuesioner, analisis dan pembahasan terhadap temuan penelitian menggunakan informasi tambahan yang diperoleh dari diskusi kelompok.
Tingkat hubungan data skor antara guru IPS pada SMP dengan kategori Baik dan Sedang menunjukkan bahwa kekuatan hubungan keduanya adalah signifikan sebagaimana yang tampak dalam tabel di bawah ini.

Berdasarkan pada kisi-kisi instrumen penelitian yang terdiri atas tiga kluster, skor yang diperoleh

Tabel 3. Korelasi Data Skor IPS

Correlations

\begin{tabular}{|c|c|c|c|c|}
\hline & & & Baik & Sedang \\
\hline \multirow[t]{6}{*}{ Spearman's rho } & \multirow[t]{3}{*}{ Baik } & Correlation Coefficient & 1.000 & $.973^{* *}$ \\
\hline & & Sig. (2-tailed) & & .000 \\
\hline & & $\mathrm{N}$ & 18 & 18 \\
\hline & \multirow[t]{3}{*}{ Sedang } & Correlation Coefficient & $.973^{* *}$ & 1.000 \\
\hline & & Sig. (2-tailed) & .000 & \\
\hline & & $\mathrm{N}$ & 18 & 18 \\
\hline
\end{tabular}

${ }^{* *}$. Correlation is significant at the 0.01 level (2-tailed). 
dari guru IPS pada SMP dengan kategori Baik dan Sedang dirinci sesuai dengan kluster tersebut sebagai berikut;

Pertama, kemampuan guru IPS di SMP dengan kriteria Baik dan Sedang untuk menjabarkan kompetensi mata pelajaran IPS yang berbasis cabang keilmuan untuk kepentingan pembelajaran terpadu tampak sebagaimana yang divisualkan dalam Ilustrasi berikut ini.

Grafik 1. Perbandingan Skor Kemampuan Guru IPS Menjabarkan Kompetensi IPS
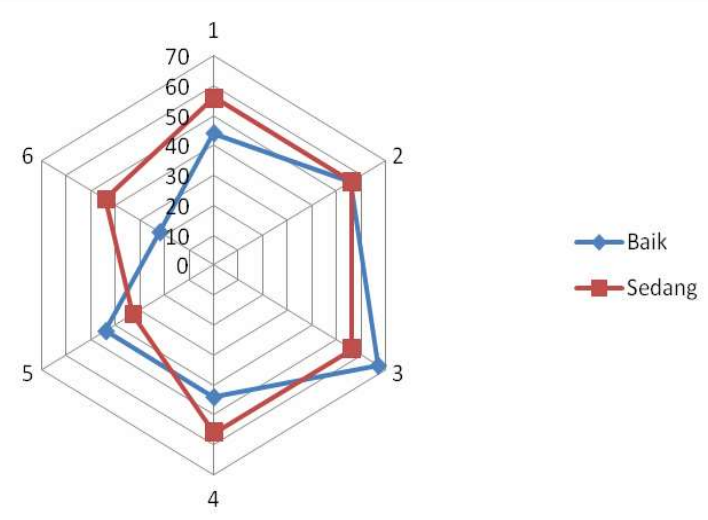

Data dari responden guru IPS SMP dengan kriteria Baik menunjukkan bahwa: 1) 44\% guru menyusun silabus secara khusus untuk pembelajaran terpadu, 2) $56 \%$ guru menyusun rencana pelaksanaan pembelajaran secara khusus untuk pembelajaran terpadu, 3) $67 \%$ guru menjabarkan kompetensi ke indikator materi secara khusus untuk pembelajaran terpadu, 4) $44 \%$ guru menjabarkan indikator materi ke dalam bahan pelajaran untuk pembelajaran terpadu, 5) $44 \%$ guru merumuskan konsep tematik secara khusus untuk pembelajaran terpadu, dan 6) $22 \%$ guru menjabarkan konsep tematik secara khusus untuk pembelajaran terpadu.

Data dari responden guru IPS SMP dengan kriteria Sedang menunjukkan bahwa: 1) $56 \%$ guru menyusun silabus secara khusus untuk pembelajaran terpadu, 2) 56\% guru menyusun rencana pelaksanaan pembelajaran secara khusus untuk pembelajaran terpadu, 3) $56 \%$ guru menjabarkan kompetensi ke indikator materi secara khusus untuk pembelajaran terpadu, 4) $56 \%$ guru menjabarkan indikator materi ke bahan pelajaran secara khusus untuk pembelajaran terpadu, 5) $33 \%$ guru merumuskan konsep tematik secara khusus untuk pembelajaran terpadu, dan 6) $44 \%$ guru menjabarkan konsep tematik secara khusus untuk pembelajaran terpadu.

Kedua, pandangan guru IPS di SMP dengan kriteria Baik dan Sedang yang masing-masing memiliki perbedaan latar belakang cabang keilmuan untuk melaksanakan pembelajaran terpadu tampak sebagaimana yang divisualkan dalam ilustrasi berikut ini.

Grafik 2. Perbandingan Skor Pandangan Guru IPS Terhadap Pembelajaran Terpadu

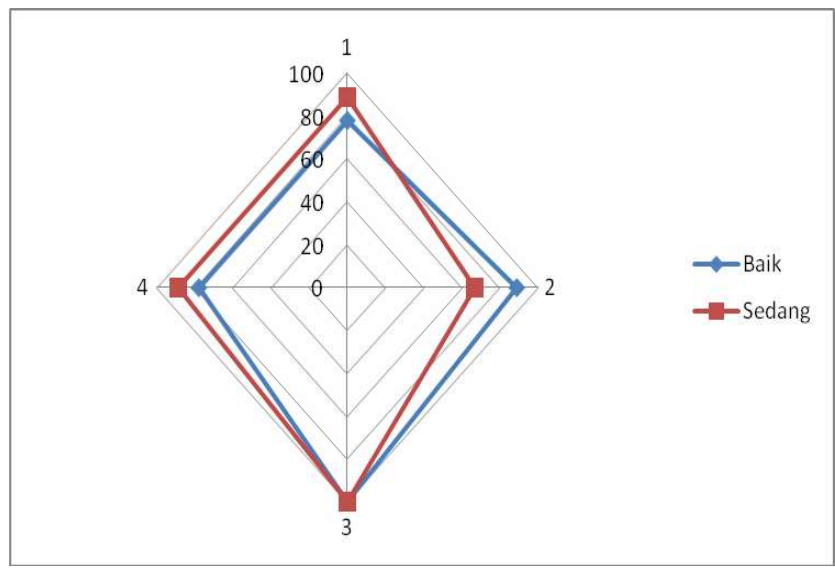

Data dari responden guru IPS SMP dengan kriteria Baik menunjukkan bahwa: 1) $78 \%$ guru menyadari bahwa latar belakang cabang keilmuan merupakan "constrain" untuk pembelajaran terpadu, 2) $89 \%$ guru menyadari bahwa konsep cabang keilmuan tertentu sulit ditematikkan dengan cabang ilmu yang lainnya untuk pembelajaran terpadu, 3) $100 \%$ guru menyadari bahwa konsep setiap cabang keilmuan memiliki karakteritik tersendiri, dan 4) $78 \%$ guru menyadari bahwa kondisi faktual kompetensi dan guru saat ini menjadi "constrain" pembelajaran terpadu.

Data dari responden guru IPS SMP dengan kriteria Sedang menunjukkan bahwa: 1) $89 \%$ guru menyadari bahwa latar belakang cabang keilmuan merupakan "constrain" untuk pembelajaran terpadu, 2) $67 \%$ guru menyadari bahwa konsep cabang keilmuan tertentu sulit ditematikkan dengan cabang ilmu yang lainnya untuk pembelajaran terpadu, 3) 100\% guru menyadari bahwa konsep setiap cabang keilmuan memiliki karakteritik tersendiri, dan 4) $89 \%$ guru menyadari bahwa kondisi faktual kompetensi dan guru saat ini menjadi "constrain" pembelajaran terpadu. 
Ketiga, kemampuan guru IPS di SMP dengan kriteria Baik dan Sedang untuk melaksanakan pembelajaran terpadu yang efektif dengan keterbatasan alokasi waktu dan jadwal pelajaran yang tidak dirancang dan disusun untuk kepentingan pembelajaran terpadu berbasis pada "team teaching" tampak sebagaimana yang divisualkan dalam Ilustrasi berikut ini.

Grafik 3. Perbandingan Skor Kemampuan Guru IPS Melaksanakan Pembelajaran Terpadu
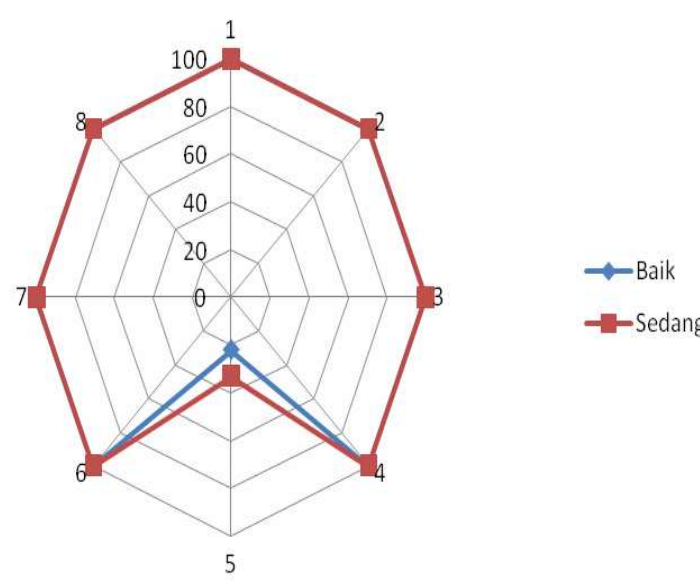

Data dari responden guru IPS SMP dengan kriteria Baik menunjukkan bahwa: 1) 100\% guru menyatakan perlu memiliki pemahaman yang komprehensif untuk melaksanakan pembelajaran terpadu, 2) $100 \%$ guru menyatakan perlu alokasi waktu yang cukup untuk pembelajaran terpadu, 3) $100 \%$ guru menyatakan perlu jadwal pelajaran yang fleksibel untuk pembelajaran terpadu, 4) $100 \%$ guru menyatakan perlu kreativitas dalam pembelajaran terpadu, 5) $22 \%$ guru menyatakan kesulitan menemukan referensi untuk pembelajaran terpadu, 6) $100 \%$ guru menyatakan adanya pedoman yang jelas dan mudah dicari untuk pembelajaran terpadu, 7) $100 \%$ guru menyatakan perlu dukungan kebijakan untuk pembelajaran terpadu, dan 8) $100 \%$ guru menyatakan perlu dukungan sumber daya pendidikan untuk pembelajaran terpadu.

Data dari responden guru IPS SMP dengan kriteria Sedang menunjukkan bahwa: 1) 100\% guru menyatakan perlu memiliki pemahaman yang komprehensif untuk melaksanakan pembelajaran terpadu, 2) $100 \%$ guru menyatakan perlu alokasi waktu yang cukup untuk pembelajaran terpadu, 3) $100 \%$ guru menyatakan perlu jadwal pelajaran yang fleksibel untuk pembelajaran terpadu, 4) $100 \%$ guru menyatakan perlu kreativitas dalam pembelajaran terpadu, 5) 33\% guru menyatakan kesulitan menemukan referensi untuk pembelajaran terpadu, 6) $100 \%$ guru menyatakan adanya pedoman yang jelas dan mudah dicari untuk pembelajaran terpadu, 7) $100 \%$ guru menyatakan perlu dukungan kebijakan untuk pembelajaran terpadu, dan 8) $100 \%$ guru menyatakan perlu dukungan sumber daya pendidikan untuk pembelajaran terpadu.

Studi ini termasuk ke dalam penelitian deskriptif yang diarahkan pada penemuan informasi mengenai efektivitas pembelajaran terpadu mata pelajaran IPS. Data temuan secara keseluruhan dapat disimpulkan bahwa tingkat hubungan data skor antara guru kedua mata pelajaran tersebut pada SMP dengan kategori Baik dan Sedang menunjukkan kekuatan hubungan keduanya yang sangat signifikan.

Signifikansi kekuatan hubungan tersebut bermanfaat untuk menjawab pertanyaan mengapa studi ini diperlukan. Jawaban yang diperoleh adalah sebagai berikut:

Pertama, studi ini diperlukan untuk menghilangkan isu yang berkembang di masyarakat sekolah mengenai istilah "IPS Terpadu". Isu ini merupakan kesalahan konseptual karena sama sekali tidak ada "IPS Terpadu". Hakikat IPS adalah mata pelajaran terpadu yang konsepnya berasal dari berbagai disiplin keilmuan. IPS berasal dari konsep-konsep Sejarah, Geografi, Ekonomi, Sosiologi, dan Antropologi.

Kedua, studi ini diperlukan untuk menjelaskan bahwa penggunaan terpadu yaitu seharusnya diarahkan bagi pembelajarannya, bukan pada IPS sebagai mata pelajaran, karena pada mata pelajaran tersebut memang sudah terpadu. Sebagaimana diketahui pada sekarang ini, secara faktual bahwa pembelajaran IPS masih menggunakan pendekatan yang berbasis pada disiplin keilmuan yang menjadi latar belakang pendidikan masing-masing guru. Mereka mengajar secara linier keilmuan mulai dari latar belakang pendidikan sampai dengan penjabaran kompetensi yang terdapat dalam mata pelajaran IPS, penyusunan silabus dan rencana pelaksanaan pembelajaran, dan pelaksanaan pembelajarannya. Mengingat bahwa hakikat IPS merupakan 
mata pelajaran yang masing-masing sudah terpadu, oleh karenanya pembelajarannya pun sudah semestinya dilakukan secara terpadu. Apabila hal semacam ini tidak diperhatikan, sangat dikuatirkan akan menyebabkan misi dari IPS tidak akan pernah sepenuhnya tercapai.

Ketiga, studi ini diperlukan untuk menuntut komitmen dari seluruh unsur terkait dalam penyediaan dan pembinaan teknis guru IPS. Mata pelajaran IPS secara historis telah muncul dalam khasanah pendidikan Indonesia seiring dengan pemberlakuan Kurikulum 1975, namun sayangnya sampai saat sekarang ini belum dihasilkan guru yang memiliki kualifikasi akademik dan kemampuan yang komprehensif-integratif untuk melaksanakan pembelajaran terpadu IPS. Misi IPS tidak akan berhasil dicapai apabila gurunya masih dipertahankan dengan pola latar belakang keilmuan yang selama ini terjadi.

Hasil analisis temuan studi ini menunjukkan bahwa secara umum pembelajaran terpadu IPS belum terlaksana secara optimal, karena banyak faktor yang menjadi penyebabnya. Faktor-faktor tersebut antara lain: 1) kemampuan guru IPS di SMP untuk menjabarkan kompetensi mata pelajaran IPS menunjukkan diskrepansi yang cukup tinggi. Hal itu disebabkan oleh latar belakang pendidikan mereka yang berbasis cabang keilmuan, sehingga kepentingan pembelajaran terpadu tidak terpenuhi sebagaimana mestinya, 2) pandangan guru IPS di SMP yang masing-masing memiliki perbedaan latar belakang cabang keilmuan pada umumnya tidak bisa memaknai secara jelas maksud dilaksanakannya pembelajaran terpadu. Oleh karenanya, mereka melaksanakan pembelajaran terpadu berdasarkan pada perspektif dan kemampuan individual mereka masing-masing; dan 3) kemampuan guru IPS di SMP untuk melaksanakan pembelajaran terpadu yang efektif tidak bisa dilakukan secara optimal, karena terkendala oleh keterbatasan alokasi waktu dan jadwal pelajaran yang tidak dirancang dan/atau disusun untuk kepentingan pembelajaran terpadu yang berbasis pada pendekatan "team teaching".

\section{Simpulan dan Saran Simpulan}

Hasil penelitian ini memberikan gambaran yang jelas bahwa pembelajaran terpadu IPS di SMP tidak efektif. Kendala yang menyebabkan ketidakefektifan tersebut adalah sebagai berikut: 1) diskrepansi kemampuan guru IPS yang cukup tinggi di SMP untuk menjabarkan kompetensi mata pelajaran IPS disebabkan oleh latar belakang pendidikan mereka yang berbasis cabang keilmuan, 2) Kedua, pemaknaan yang tidak jelas terhadap misi IPS tampak dari pandangan guru IPS di SMP yang masing-masing memiliki perbedaan latar belakang cabang keilmuan, sehingga pembelajaran terpadu dilaksanakan hanya berdasarkan pada perspektif dan kemampuan individual mereka masing-masing, dan 3) pelaksanaan pembelajaran terpadu IPS di SMP tidak bisa dilakukan secara optimal, karena terkendala oleh keterbatasan alokasi waktu dan jadwal pelajaran yang tidak dirancang dan/atau disusun untuk kepentingan pembelajaran terpadu yang berbasis pada pendekatan "team teaching".

\section{Saran}

Berdasarkan pada data empirik, penelitian ini merekomendasikan bahwa untuk mengoptimalkan pembelajaran terpadu IPS perlu dilakukan hal-hal sebagai berikut:

Pertama, bagi para pemegang kebijakan: 1) Pembelajaran terpadu IPS perlu dioptimalkan dengan cara menyelenggarakan pelatihan yang dilakukan secara berkelanjutan bagi seluruh guru IPS di P4TK yang terkait, 2) Guru IPS yang mempunyai potensi pengembangan profesi dan akademik perlu diberi kesempatan untuk meningkatkan kualifikasi akademiknya di perguruan tinggi penyelenggara LPTK yang memiliki Program Studi IPS, dan 3) Pembelajaran terpadu IPS perlu dioptimalkan dengan cara penyediaan buku pedoman pelaksanaan yang jelas atau mudah dicerna, sumber belajar yang memadai, dan referensi yang mencukupi. Kedua, bagi para guru IPS: 1) Guru IPS di setiap sekolah perlu selalu berdiskusi secara berkala dalam MGMP masing-masing untuk menyusun tema, silabus, dan rencana pelaksanaan pembelajaran terpadu, 2) Guru IPS di setiap sekolah perlu memperkuat strategi pembelajaran terpadu dengan model team teaching untuk meminimalisir kekurangan dan kelemahan serta memperkuat kelebihan masingmasing individu guru, dan 3) Guru IPS di setiap 
sekolah perlu memperluas perspektif melalui pertemuan MGMP di tingkat kabupaten/kota dan provinsi serta penggunaan teknologi informasi dan komunikasi.

\section{Pustaka Acuan}

Departemen Pendidikan dan Kebudayaan, 1996. Landasan Program dan Pengembangan. Jakarta. Dewey, John. 1934. Can Education Share in Social Reconstruction?" In The Social Frontier. New York: The Macmillan Company.

Fisher, B. 1991. Joyful Learning: A Whole Language Kindergarten. Portsmouth, N.H.: Heinemann.

Huber, M. T., Hutchings, P., \& Gale, R. 2005. Integrative Learning for Liberal Education. Peer Review, Summer/Fall.

Hursh, W. David dan Wayne E. Ross. 2000. Democratic Social Education Social Studies for Social Change. New York \& London: Fulmer Press.

Klein, J. T. 1996. Crossing boundaries: knowledge, disciplinarities, and interdisciplinarities: University Press of Virginia.

Kostelnik, M.J., Soderman, A.K., \& Whiren, A.P. 2004. Developmentally Appropriate Curriculum: Best Practices in Early Childhood Education. Upper Saddle River, NJ: Merrill.

Krogh, S. 1990. The Integrated Early Childhood Curriculum. New York: McGraw-Hill.

National Council for the Social Studies. 1994. Expectations of Excellence Curriculum Standards for Social Studies. Washington, DC: NCSS.

National Council for the Social Studies. 2000. Expectations of Excellence Curriculum Standards for Social Studies. Washington, DC: NCSS.

Permendiknas No. 22 tahun 2006 tentang Standar Isi

Shaver P. James, dan Berlak Harold. 1968. Democracy, Pluralism, and Social Studies. Readings and Commentary. New York: Macmillan Publishing Company.

Shoemaker, B. 1989. "Integrative Education: A Curriculum for the Twenty-First Century." Oregon School Study Council, 33/2.

Undang-Undang Republik Indonesia Nomor:20 Tahun 2005 tentang Sistem Pendidikan Nasional 